\title{
A Social Audit Model for Agro-biotechnology Initiatives in Developing Countries: Accounting for Ethical, Social, Cultural, and Commercialization Issues
}

\author{
Obidimma Ezezika', Fiona Thomas², Jim Lavery ${ }^{3}$, Abdallah Daar $^{4}$, Peter Singer ${ }^{5}$
}

\begin{abstract}
There is skepticism and resistance to innovations associated with agro-biotechnology projects in the developing world, leading to the possibility of failure. The source of the skepticism is complex, but partly traceable to how local communities view genetically engineered crops, public perception on the technology's implications, and views on the role of the private sector in public health and agriculture, especially in the developing world. We posit that a governance and management model in which ethical, social, cultural, and commercialization issues are accounted for and addressed is important in mitigating the risk of project failure and improving the appropriate adoption of agro-biotechnology in sub-Saharan Africa. We introduce a social audit model, which we term Ethical, Social, Cultural and Commercialization (ESC ${ }^{2}$ ) auditing, and that we developed based on feedback from a number of stakeholders. We lay the foundation for its importance in agrobiotechnology development projects and show how the model can be applied to projects run by Public Private Partnerships. We argue that the implementation of the audit model can help build public trust through facilitating project accountability and transparency. The model also provides evidence on how ESC ${ }^{2}$ issues are perceived by various stakeholders, which enables project managers to effectively monitor and improve project performance. Although this model was specifically designed for agro-biotechnology initiatives, we show how it can also be applied to other development projects.
\end{abstract}

Key words: Social auditing; public-private partnerships; agro-biotechnology; environmental accounting.

\footnotetext{
I McLaughlin-Rotman Centre for Global Health, University Health Network, Toronto, Canada. Email: obidimma.ezezika@mrcglobal.org

2 McLaughlin-Rotman Centre for Global Health, University Health Network, Toronto, Canada. Email: fiona.thomas@mrcglobal.org

${ }^{3}$ Centre for Research on Inner City Health and Centre for Global Health Research. Keenan Research Centre in the Li Ka Shing Knowledge Institute of St. Michael's Hospital. Assistant Professor Dalla Lana School of Public Health and Joint Centre for Bioethics University of Toronto 70 Richmond St. E., 4th Floor Toronto, Ontario M5B IW6. Email: jim.lavery@utoronto.ca

${ }^{4}$ McLaughlin-Rotman Centre for Global Health, University Health Network, Toronto, Canada. Dalla Lana School of Public Health, University of Toronto, Toronto, Canada. Email: a.daar@utoronto.ca

${ }^{5}$ McLaughlin-Rotman Centre for Global Health, University Health Network, Toronto, Canada. Dept of Medicine, University of

Toronto, Toronto, Ontario, Canada. Email: peter.singer@mrcglobal.org
} 


\section{Introduction}

Agro-biotechnology public private partnerships (PPPs) are viewed as important means of making the benefits of agrobiotechnology available in the developing world (World Development Report 2008). On the private sector side, life science firms provide genes and biotechnology research capacity, which complement the assets of the public partners such as national and international agricultural research institutes (for example, Consultative Group on International Agricultural Research, CGIAR). These assets include local or national knowledge germplasm collections, conventional breeding programs, seed distribution, and marketing research material. There has been a particular increase in agro-biotechnology PPPs focused on genetically modified (GM) crops in developing countries over the last decade (World Development Report 2008).

In 2008, the Water Efficient Maize for Africa (WEMA) project, funded by the Bill \& Melinda Gates Foundation (BMGF) and the Howard Buffet Foundation (HBF), was created to provide royalty-free maize to small-scale African farmers by 2018 or earlier. The goal of the project is to increase productivity for poor farmers in sub-Saharan Africa and give them access to crops that can protect them from frequent drought. The project is led by the African Agricultural Technology Foundation (AATF), partnering with Monsanto, a private United States (US)-based seed company, and the International Maize and Wheat Improvement Center (CIMMYT), a research center of the CGIAR.

Given the scale of the project and its multiple partners, one important concern has been to ensure that the intended humanitarian outcomes are achieved while at the same time building trust among partners, and between the project and public. In order to realize this goal, we developed and here present a social audit model that can be employed to increase transparency and enhance project accountability with stakeholders, with the aim of building public trust (Figure I). Stakeholders are those members of the community who have some stake, interest, and/ or concerns regarding the project in question. They may not be aware of the project but are likely a consumer or recipient of products or services resulting from the project. Just as key stakeholders may be affected by the project, they also play an important role in influencing the progress of the project (Pearce \& Kay 2005). In agrobiotechnology PPPs, stakeholders are usually interested in who receives the ultimate benefits of the project and what legal agreements are in place to ensure that the farmers and the community do benefit.

The model was developed and designed for the social auditing of the WEMA project. Social audits can be defined as an independent means of identifying, measuring, and reporting the ethical, social and environmental impact that a project has (Johnson 200I).

Although the concept of social auditing is not new, we are unaware of any social audit models developed for use with agro-biotechnology projects. The applicability of most previous general social audits is limited as these have tended to deal with single companies and organizations rather than PPPs, which have a different organizational structure. In addition, the assessment of ethical, social, cultural and commercialization (ESC ${ }^{2}$ ) issues in agro-biotechnology projects in developing countries has tended to be rare, and when present, invokes general issues that may not be project-specific. In this article, we briefly analyze the challenges encountered in agro-biotechnology initiatives in relation to public trust. Using our experience developing social auditing services for the WEMA project, we present a model for the social auditing of agro-biotechnology initiatives that are run by PPPs. We show how an accounting of ethical, social, cultural, and commercialization factors, which we call ESC ${ }^{2}$ factors, through a social audit process could foster accountability and transparency. We propose that social auditing could and should become an important element of agro-biotechnology development projects in accounting for and addressing $\mathrm{ESC}^{2}$ issues.

\section{The Issue of Trust in Agro-Biotechnology Development Initiatives}

Stakeholder trust is crucial for companies and influences consumer spending, corporate reputation, and the ability of companies to navigate the regulatory environment (Edelman 2009). Lack of mutual trust and clashes of private and public cultures were identified as primary stumbling blocks to the promise of agro-biotechnology PPPs in the developing world (World Development Report 2008). For the purpose of this paper, we use a multidisciplinary 
definition of trust developed by Rousseau et al (1998) where trust is defined as "a psychological state comprising the intention to accept vulnerability based upon positive expectations of the intentions or behaviours of another" (Rousseau et. al. 1998, p. 395).

The issue of trust is also important to PPPs working on agro-biotechnology because GM crops in agriculture are controversial and considered risky in some communities. In traditional agricultural regions, especially in Africa, indigenous food crops have deep cultural and religious significance. As a result, innovations affecting crops are perceived with distrust, which can increase the risk of failure of agro-biotechnology initiatives. Examples of failed agro-biotechnology initiatives due to mistrust are prevalent worldwide. For example, civil society organizations led the uprooting of all GM maize planted in Malawi in 2003 due to public health concerns (Bokor, 2004). A year earlier, the Zambian government rejected GM food aid offered by the US due to concerns by the government and about the health and environmental implications of the grains (Maharaj 2002; Manda 2003). In Kenya, there was poor adoption of drought tolerant sorghum, which commentators have attributed to poor consultation with farmers, plant breeders, extension agents and social scientists that resulted in public distrust and skepticism among community members; hence the project's failure (Oduol 1995).

Public mistrust in agro-biotechnology projects run by PPPs can also arise from public fear of corporate control of agriculture and its benefits. This is not unfounded as the global seed trade is currently dominated by a handful of giant corporations (Jordan 2002). Dominance of the global seed market by private companies is perceived to retract control that farmers have over traditional farming practices of seed recycling, subsequently leading to their reliance on private companies for seeds. National governments also fear relinquishing their food security sovereignty to the private sector due to their emerging dominance of the global seed market (ETC Group 2008). According to Action Group on Erosion, Technology and Concentration (2008), almost $70 \%$ of the global proprietary seed market is controlled by the top 10 seed companies. In addition, the top 3 companies (Monsanto, DuPont, Syngenta) together account for about half of the worldwide proprietary seed market (ETC Group 2008).
In recent years, a number of large-scale science initiatives such as the Human Genome project set aside part of its funding to address ethical, legal and social issues associated with the project (Dove 1998; Meslin, Thomson, \& Boyer, 1997) with the intention of building trust. In addition, pharmaceutical and biotechnology companies have incorporated internal ethics offices or ethics consultants, or implemented sustainability reporting with the hope of building trust with customers and stakeholders (Finegold et al 2005). Other mechanisms developed to build trust and accountability have included disclosure statements and reports, performance assessment and evaluation, participation, and self-regulation (Ebrahim 2003). These methods reflect either upward accountability (such as performance assessments) or downward accountability (such as participation and community engagement), where upward accountability is responsibility mainly towards donors and funders and downward accountability is directed towards stakeholders (Ebrahim 2003). However, social audit is more inclusive because it places accountability internally (among the partners) and externally to donors and stakeholders.

\section{Social Audit as a Trust Building Tool}

Social auditing is regarded as an important tool in building trust (Gao \& Zhang 2006), and improving accountability and transparency (Zadek \& Raynard, 1995; Ebrahim 2003; O'Dwyer, 2005). We define it as a process whereby an audit team collects, analyses, and interprets descriptive, quantitative and qualitative information from stakeholders to produce an account of a project's ethical, social, cultural and commercialization performance and impact.

Social auditing can be likened to financial auditing (Table I): Performance data are collected, and the data are reviewed by an independent and external expert (auditor) who verifies that the information is accurate. The auditor issues a statement confirming the accurate representation of the business or project. The difference between these processes is that financial auditing deals with financial accounts while social auditing is focused on social accounts. There is also a difference in development: financial auditing has been around for several hundred years and has generally accepted principles and standards while social auditing is in its early stages of development. 
Social auditing has been practiced since the 1970s and some of the earliest known examples were conducted by Abt Associates, a US consultancy firm that incorporated social audit accounts into its own annual report (Abt Associates, 1976). However, it was not until the 1990s that the practice took a more systematic approach (Henriques 2000). A group of companies and organizations, including the National Economics Foundation (a UK think-tank) and Traidecraft, a trading and charity company, came together to form the Institute of Social and Ethical Accountability. Through the Institute and other ventures, a number social audit models were developed (Dey 2007; Raynard 1998). The goals of these models were to make an organization more transparent and accountable and to re-orient the activities of organizations towards the interests of its stakeholders (Zadek \& Raynard 1995). Although not widespread, non-profit organizations and social enterprises have also practiced social auditing (Ebrahim 2003). For example, CIET in Pakistan, an academic NGO, has conducted a community-based social audit in two districts in Afghanistan to document community experiences and views of health service performance with the purpose of raising the quality of health services and minimizing inefficiencies (IDRC 2008).

Private companies and businesses have also been interested in the application of social auditing for the purpose of moving their companies towards environmental sustainability and long-term profitability through the development of sustainability reports. Sustainability reporting is a form of social auditing that is tailored for businesses and incorporates the principle of sustainable development. There has been an increase in sustainability reporting by companies over the last decade. According to CorporateRegister.com, a directory of Corporate Social Responsibility (CSR) resources, the number of sustainability reports increased from 462 in 1998 to almost 3,000 in 2008. Companies seem to be realizing that sustainability reporting is essential in improving trust with customers and stakeholders. Nike, for example, through its sustainability reporting initiative has been said to have steadily transformed its relationship with customers and stakeholders, and improved work practices (Zadek 2004).

The social audit model introduced here differs from other popular social audit models in two major ways: first, our model is tailored to projects run by PPPs. For example, the New Economics Foundation (NEF) model has been applied to a number of organizations including some public and others private (Zhang et al 2003), but not to PPPs or projects run by PPPs. Secondly our model deals with improving internal management and strengthening public accountability, not one or the other exclusively. For example, the Traidcraft and Body Shop models are primarily a means of strengthening public accountability while the Beechwood model was designed primarily as an internal management system thus obviating the need to disclose the results publically (Zhang et al, 2003). The Beechwood model, along with other common social audits, was designed to be used by an organization to assist in planning, managing and measuring social accounts in response to the challenges from social and environmental concerns (Zhang et al, 2003). Our model is designed to advise management so that they may improve their practices and to strengthen public accountability and transparency with stakeholders.

Learning from these previous models and taking into account the intended goals of the WEMA project, we developed a social audit model tailored to agrobiotechnology PPPs and stakeholder engagement, which we applied to the WEMA project in 2008. In the following section, we describe how this model was developed, how it can be applied to agro-biotechnology projects, and its potential to be franchised to other development projects.

\section{A Social Audit Model for Agro-biotechnology Projects}

To develop a social audit model for agro-biotechnology projects, we created a framework that took into account the goals of the WEMA project, which generally covers all aspects of a typical agro-biotechnology initiative managed by a public private partnership. The goals of the WEMA project are divided into seven major components and include: technical, regulatory, deployment, capacity building, charitable purpose, project management and governance, and communication.

We refer to these seven components as audit lenses, and they are shown in Figure 2. In the model, these lenses shape the four processes through which ESC $^{2}$ issues are made explicit. These processes include: I) Interview with stakeholders; 2) Focus Groups with farmers; 3) Review of project reports and; 4) Meeting Observations (Figure 2). For the stakeholder interviews and focus groups, we 
developed 2 questionnaires, one with closed-ended questions and the other with open-ended questions, which reflected the seven audit lenses. The closed-ended questions, which were administered first in the interviews, were analyzed numerically while the open-ended questions were part of an interview guide. Samples of the questions are shown in Table 3. These questions were stakeholderspecific.

The questionnaires were carefully designed to uncover $E^{2} C^{2}$ issues in the project. These questionnaires were first piloted with 17 internal interviewees within the WEMA teams. Based on the feedback we received from the interviews with internal stakeholders, we revised the audit tools, and then piloted the revised tools through face-toface interviews with 26 external stakeholders to the WEMA project. The main feedback from internal stakeholders was to improve the clarity of some of the questions in the closed-ended questionnaire and to simplify and standardize the open-ended questionnaire. The main recommendation from external interviewees was to expand the stakeholder groups. The open and closedended questionnaires were finalized following the pilot interviews with internal and external stakeholders. Thereafter, we conducted 50 face-to-face interviews and administered the finalized questionnaires. In total, 101 interviews were conducted.

Although $\mathrm{ESC}^{2}$ issues identified by key stakeholders became primarily clear through stakeholder views and focus groups, meeting observations and project reports were also important in the process. The final phase in our model (Figure 2) was the communication of the social audit results to funders, partners and the stakeholders through a report, which included details of how the social audit was conducted; key findings from the interviews; $\mathrm{ESC}^{2}$ issues that arose from our review of project reports and observation at meetings and recommendations to the grantors (BMGF and HBF) and project managers of WEMA on how the $\mathrm{ESC}^{2}$ issues raised by stakeholders can be addressed in the following year of the project.

According to our model, once the social audit is completed and key concerns from stakeholders are shared with the project team managers, the project managers provide a management response. Both the report and the management response are shared with stakeholders to foster transparency and accountability. Some of the $\mathrm{ESC}^{2}$ issues that arose mainly revolved around intellectual property rights, seed cost concerns, seed control, and communication ${ }^{6}$.

\section{Lessons learned}

There were important lessons from our audit, which could be applicable to other social audit programs. We found that it was important to develop the stakeholder list in conjunction with the project being audited. For example, the target audiences for the WEMA audit mirrored the ones identified in WEMA's own communication strategy. As these broaden through the life of the WEMA project, the audiences for the social audit will broaden simultaneously. We adopted this approach in order to obviate any damaging effects to the WEMA Project that could occur by raising broad public awareness about the audit before WEMA has had an opportunity to raise awareness about the goals of their project. Through our meetings with various stakeholders, it was obvious that some issues varied by region and each country had its own unique obstacles including different perceptions on GM crops and regulatory challenges.

In addition, some interviewees were not fully familiar with the WEMA project when we conducted the social audit; this showed us the importance of project knowledge. We found that opinion was dependent on knowledge of the Project. Generally, if an interviewee lacked knowledge of the Project, their opinion of the Project was low and when they had a better knowledge of the project, they had a more favorable opinion. A number of interviewees attributed their poor knowledge of the project to the early nature of the project. However, we found it was important to conduct an audit early in the project in order to establish a baseline for $\mathrm{ESC}^{2}$ issues and project evaluation and track them over the life of the project. Finally, we observed that interviewees were very happy to be consulted in the audit process and realized the importance of providing a fair and diverse representation of all stakeholders to satisfy the principle of inclusivity.

\section{Application of Social Audit Model to other Development Projects}

Although the model presented here was specifically tailored to agro-biotechnology initiatives, it can be

${ }^{6}$ Detailed ESC ${ }^{2}$ findings are published in Annual Social Audit Reports

ISSN: 07I8-2724. (http://www.jotmi.org)

Journal of Technology Management \& Innovation (C) Universidad Alberto Hurtado, Facultad de Economía y Negocios 
applicable to other life science and health development projects by taking into account the following five principles. These principles were important in performing the social audit of the WEMA project.

I. Creation of a framework based on the intended goals of the project and the stakeholders involved.

2. Identification of stakeholder groups and the application of the principles of inclusivity and materiality in stakeholder involvement.

3. Engagement of stakeholders in designing the questionnaires and pilot testing of tools that will be used in the social audit.

4. Development of a system to communicate the results to partners, funders and the public in order to ensure transparency.

5. Use of an accountability system in which management can be held accountable by the funders and governance in addressing the findings of the audit.

These principles reflect the importance of stakeholder engagement, transparency and accountability, which are important in fostering trust among partners and between partners and stakeholders. The model is simple, straightforward, and easy to implement. It can be tailored to other projects managed by public private partnerships in the health and life science sectors, by creating a framework based on the intended goals of the project to be audited and following the principles outlined above.

Although there are inevitable disadvantages associated with social audit such as cost and time commitment (Dawson, 1998), social audits can be feasible when an organization does what is "possible, realistic and manageable" (Social Audit Network, 2005). It is best to start small and scale-up as necessary. According to SAN (2005) and through our experience, costs significantly reduce in the second and subsequent years once systems are set up and processes are refined. With busy schedules, lengthy agendas and limited time, organizations generally view social audits as superfluous and prefer not to invest extensive time in it. However, our experience has shown that the time required in preparing for and conducting a Social Audit decreases in subsequent years and the benefits that could accrue in terms of accountability, transparency and building trust with stakeholders can be crucial to project success and stakeholder confidence.

Although the WEMA project and social audit processes are still in their early stages, we will continue to evaluate the impact of the audit on project transparency, accountability and its direct impact on fostering trust with the community and among the partners.

\begin{tabular}{|l|l|}
\hline \multicolumn{1}{|c|}{ FINANCIAL AUDIT } & \multicolumn{1}{c|}{ SOCIAL AUDIT } \\
\hline $\begin{array}{l}\text { Performance data are collected by } \\
\text { management/employees }\end{array}$ & $\begin{array}{l}\text { Performance data are collected } \\
\text { through interviews, } \\
\text { observations/ and focus groups }\end{array}$ \\
\hline $\begin{array}{l}\text { Independent/external audit team reviews the } \\
\text { data }\end{array}$ & $\begin{array}{l}\text { Independent/external audit team } \\
\text { reviews the data }\end{array}$ \\
\hline $\begin{array}{l}\text { Auditor/team issues a statement on whether } \\
\text { the data are a fair presentation of the affairs } \\
\text { of the business }\end{array}$ & $\begin{array}{l}\text { Audit team submits a report on } \\
\text { whether the data reflect the } \\
\text { goal(s) of the project }\end{array}$ \\
\hline Financial accounts & Social Audit accounts \\
\hline Shareholders & Stakeholders \\
\hline
\end{tabular}

Table I. Differences between a social audit and a financial audit 


\begin{tabular}{|c|c|}
\hline AUDIT LENS & STAKEHOLDER GROUPS \\
\hline I. TECHNICAL & $\begin{array}{l}\text { - Technical Resource } \\
\text { - Technical Personnel in Project }\end{array}$ \\
\hline 2. REGULATORY & $\begin{array}{l}\text { - Regulatory Personnel } \\
\text { - Agro-biotech Regulatory consultants }\end{array}$ \\
\hline 3. CAPACITY BUILDING & - National Agricultural Research Services \\
\hline 4. DEPLOYMENT & $\begin{array}{l}\text { - Farmers } \\
\text { - Agricultural Extension services } \\
\text { - Maize processors/Millers } \\
\text { - Farmers Groups } \\
\text { - Consumers }\end{array}$ \\
\hline 5. GOVERNANCE & $\begin{array}{l}\text { - Grantors } \\
\text { - Legal Consultants } \\
\text { - Partners }\end{array}$ \\
\hline 6. CHARITABLE GOAL & $\begin{array}{l}\text { - Partner Organizations } \\
\text { - National Authorities } \\
\text { - NGOs }\end{array}$ \\
\hline 7. COMMUNICATION & $\begin{array}{l}\text { - Media Outreach } \\
\text { - General Public }\end{array}$ \\
\hline
\end{tabular}

Table 2. Social Audit Lens and Associated Stakeholder Groups

Quantitative Questionnaire (Scale: Excellent=5; Very Good =4; Good=3; Fair=2; Poor=I and Don't Know)

- What is your level of knowledge of the Water Efficient Maize for Africa (WEMA) Project?

- How well have the interests and concerns of the general public been considered in project planning and implementation?

- How effective is the communication strategy in listening, learning and making changes based on feedback from the public?

Interview Guide (Open Ended)

- What ethical, social, and/or cultural issues have been encountered by the public?

- What potential commercialization issues do you foresee in the project and have preparations been made by the WEMA partners to effectively address these issues if and when thev arise?

Table 3. Sample questions: The quantitative questionnaire was administered first, which was followed up with the open-ended interview guide 


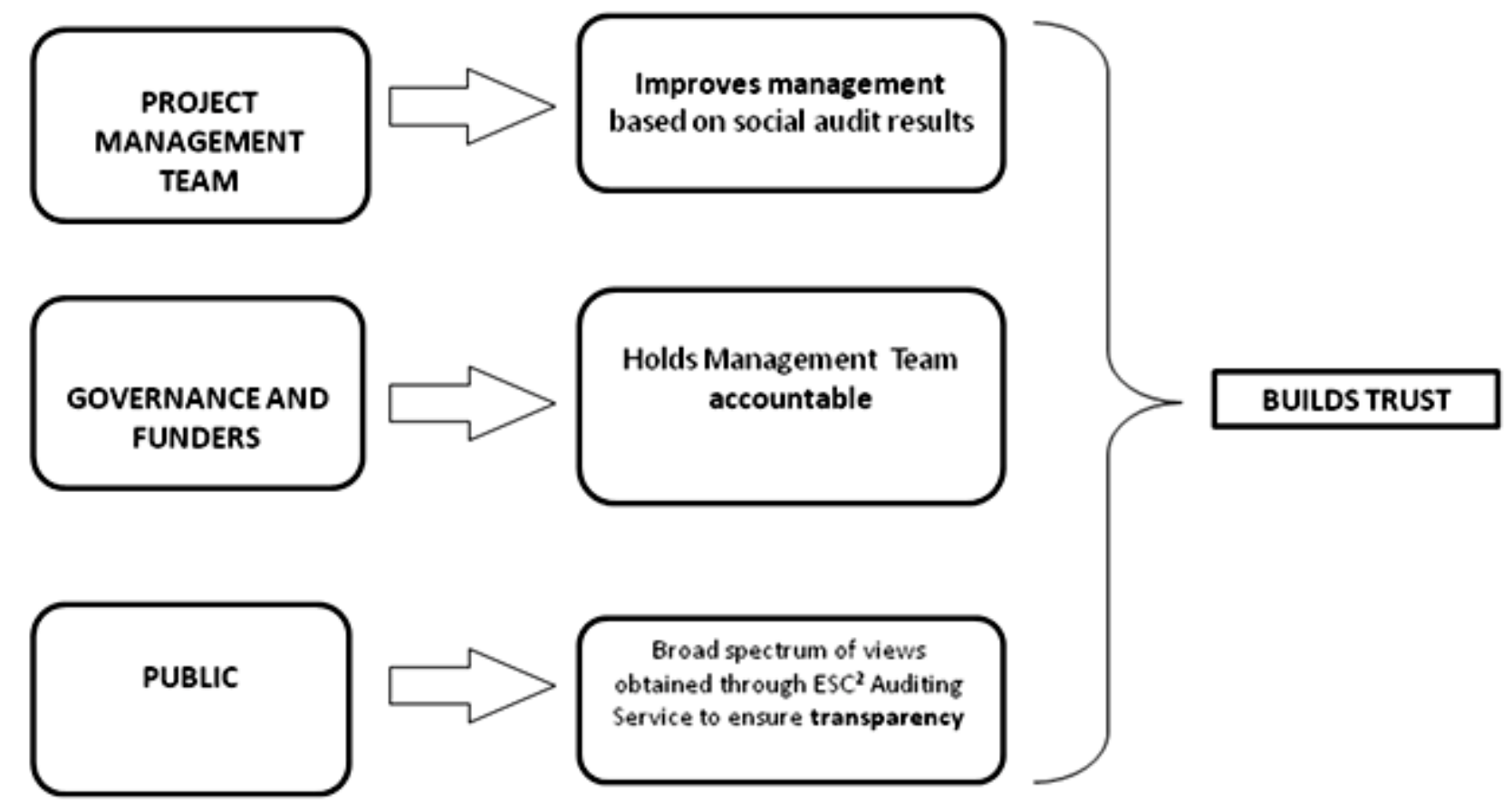

Figure I. Building Trust through a Social Audit

The social audit will help foster improved management practices, accountability and transparency, which in turn will help to build trust both among the partners in a project, and between the project and the public.

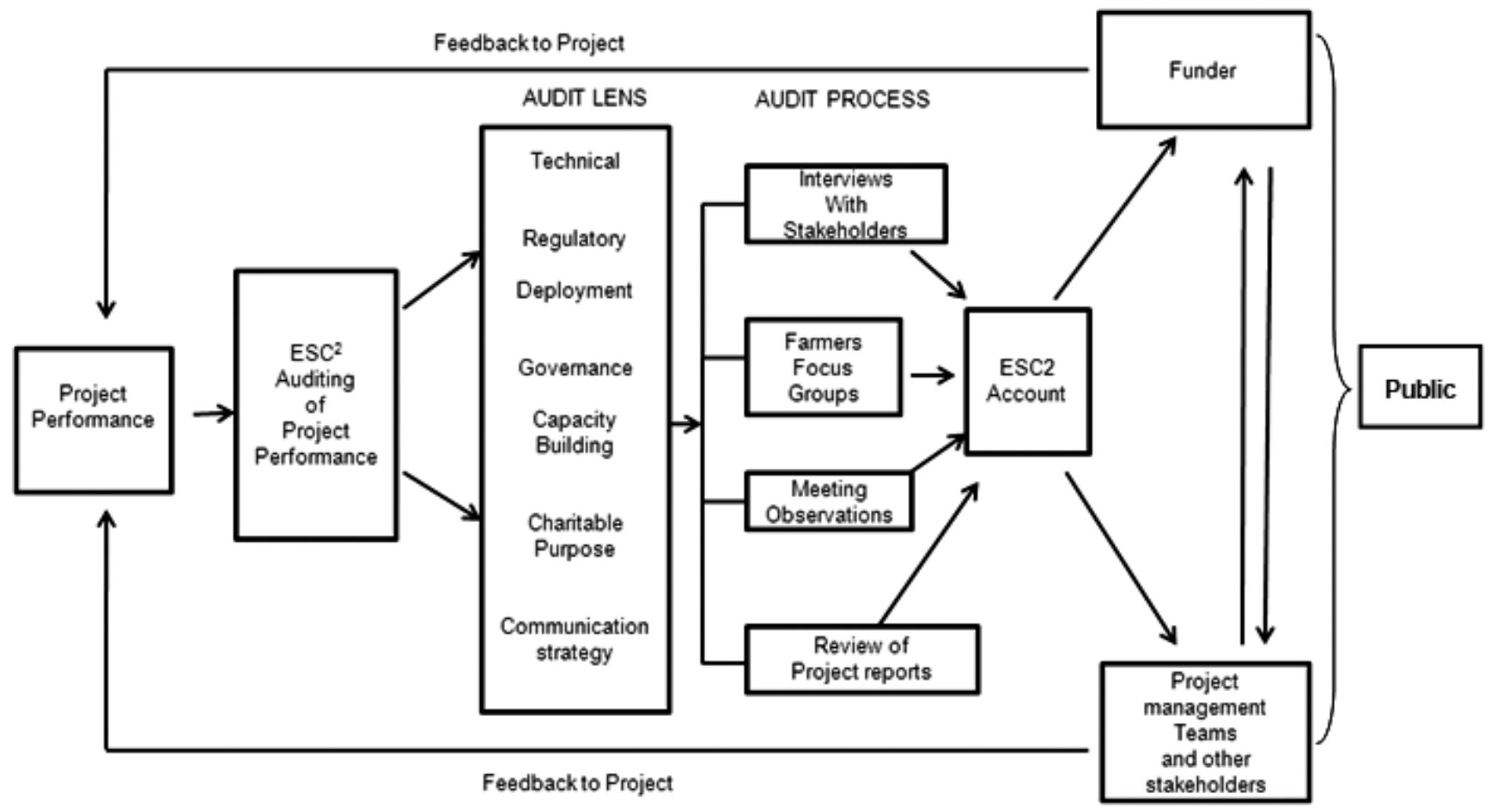

Figure 2. ESC ${ }^{2}$ Audit Model for the Agro-biotechnology Projects 
The model is premised on a one year project cycle in which an ESC $^{2}$ account is produced. The results and recommendations of the ESC ${ }^{2}$ account produced through the audit process are fed back into the next cycle through the Grantors and the Pls of the project. The critical component of the audit process is the engagement of stakeholders and focus groups with farmers. The observation of meetings and project reports is crucial; it is mainly from these engagements that views and issues of key stakeholders become palpable. All four audit processes are performed through a lens network, which have been designed to account for all aspects and phases of the project. After the first cycle, depending on the $\mathrm{ESC}^{2}$ issues that were raised, a series of indicators are developed to track the incorporation of these changes in subsequent years.

\section{Acknowledgements}

We are grateful to Jocalyn Clark for her comments on earlier drafts of the manuscripts.

\section{Funding}

This publication was funded by the Bill \& Melinda Gates Foundation. The findings and conclusions contained within are those of the author and do not necessarily reflect official positions or policies of the Bill \& Melinda Gates Foundation.

\section{References}

Demonstration Community-Based Social Audit of Health Services in two Districts of Afghanistan2008, Available: http://www.idrc.ca/geh/ev-I29438-20I-I-DO TOPIC.html (2009, July 16).

World development report 2008: agriculture for development. 2007, World Bank, Washington, D.C.

Bioindustry ethics, (2005). Elsevier Academic Press, Boston, Mass.

Perspectives on corporate citizenship, (200I). Greenleaf, Sheffield.

The co-operative Sustainability Report: Altogether Different and Making a Difference.
Social Accounting: FTSE4Good Index Series. Available: http://www.bized.co.uk/learn/accounting/management/socia l/ftse.htm (2009, July/20).

Abt Associates, I. (1976). Annual Report and Social Audit.

Audit Commission (2003). The LHT Group: Inspection Report, UK.

BOKOR, R.K. (2004). Resistance to Genetic Engineering in Africa, Synthesis/Regeneration: A Magazine of Green Social Thought.

CHASSY, B.M. (2007). The history and future of GMOs in food and agriculture. Cereal Foods World, vol. 52, no. 4, Pp. I69-172.

COUPLAND, C. (2006). Corporate social and environmental responsibility in web-based reports: Currency in the banking sector?. Critical Perspectives on Accounting, vol. 17, no. 7, pp. 865-88I.

DAWSON, E. (1998). The Relevance of Social Audit for Oxfam GB. Journal of Business Ethics, vol. 17, no. 13, Social and Ethical Accounting, Auditing and Reporting, pp. I4571469.

DEY, C. (2007). Social accounting at Traidcraft plc. Accounting, Auditing \& Accountability Journal, vol. 20, no. 3, pp. 423-445.

DOVE, A. (1998). Genetics research on the town hall agenda, courtesy of ELSI. Nature medicine, vol. 4, no. 5, PP. 541 .

EBRAHIM, A. (2003). Accountability in Practice: Mechanisms for NGOs. World Development, vol. 3I, no. 5, pp. 813-829.

EDELMAN (2009). Edelman Trust Barometer: The Tenth Global Opinion Leaders Study.

EICHER, C.K., Maredia, K., Sithole-Niang, I. "Crop biotechnology and the African farmer", Food Policy, vol. 31, no. 6, pp. 504-527.

ETC Group (2008). Who Owns Nature? Corporate Power and the Final Frontier in the Commodification of Life. 
FTSE 2008, FTSE4Good Index Series. http://www.ftse.com/ Indices/FTSE4Good_Index_Series/index.jsp (2009, July/20).

GAO, S.S., Zhang, J.J. (2006). Stakeholder engagement, social auditing and corporate sustainability. Business Process Management Journal, vol. 12, no. 6, pp. 722-740.

HARVEY, B. (1995). Ethical Banking: The Case of the Cooperative Bank. Journal of Business Ethics, vol. 14, no. 12, pp. 1005-1013.

HENRIQUES, A. (2000). Social audit \& quality. Quality Focus, vol. 4, no. 2, pp. 60-64.

JOHNSON, H.H. (200I). Corporate Social Audits - This Time Around. Business Horizons, vol. 44, no. 3, pp. 29-36.

JORDAN, M.C. (2002). The Privatization of Food: Corporate Control of Biotechnology. Agronomy Journal, vol. 92, no. 4, pp. 803-806.

MAHARAJ, D. (2002). Zambia Rejects Gene-Altered U.S. Corn, Eddy W. Hartenstein.

MANDA, O. (2003). Controversy rages over 'GM' food aid. Africa Recovery, vol. 16, no. 4, pp. 5.

MESLIN, E.M., Thomson, E.J., Boyer, J.T. (1997). The Ethical, Legal, and Social Implications Research Program at the National Human Genome Research Institute. Kennedy Institute of Ethics journal, vol. 7, no. 3, pp. 29I-298.

Nuffield Council on Bioethics (2004). The Use of Genetically Modified Crops in Developing Countries.

O'DWYER, B. (2005). The construction of a social account: a case study in an overseas aid agency. Accounting, Organizations and Society, vol. 30, no. 3, pp. 279-296.

O'DWYER, B. (2005). The construction of a social account: a case study in an overseas aid agency. Accounting, Organizations and Society, vol. 30, no. 3, pp. 279-296.

OGBU, O.M., Banji, O.O., Mlawa, H.M. [eds] (1995). Technology Policy and Practice in Africa, International Development Research Centre.

PEARCE, J., Kay, A. (2005). Social Accounting and Audit: The Manual, Social Audit Network.
RAYNARD, P. (1998). Coming Together. A Review of Contemporary Approaches to Social Accounting, Auditing and Reporting in Non-profit Organisations. Journal of Business Ethics, vol. 17, pp. I47I-1479.

REBERNAK, K. (2006). June 20 2006-last update, Merck's 2005 corporate responsibility report: When caution curtails innovation [Homepage of Ethical Corporation], [Online]. http://www.ethicalcorp.com/content.asp? ContentlD=4329.

ROUSSEAU, D.M., Sitkin, S.B., Burt, R.S., Camerer, C. (1998). Not so Different After All: a Cross-Discipline View of Trust. Academy of Management Review, vol. 23, no. 3, pp. 393-404.

SINGER, P.A., Taylor, A.D., Daar, A.S., Upshur, R.E.G., Singh, J.A., Lavery, J.V. (2007). "Grand Challenges in Global Health: the ethical, social and cultural program.(Policy Forum)", PloS Medicine, [Online], vol. 4, no. 9, Pp. I440(5). http://www.plosmedicine.org/article/info:doi//0.137//journ al.pmed.0040265.

The Co-Operative Financial Services, Why we have ethical policies. Available: http://www.goodwithmoney.co.uk/whydo-we-need-ethical-policies/ (2009, July/2I).

VARZAKAS, T.H., Arvanitoyannis, I.S., Baltas, H. (2007). The politics and science behind GMO acceptance. Critical reviews in food science and nutrition, vol. 47, no. 4, pp. 335361 .

YIN, R.K. (2009). Case study research: design and methods, 4th ed. edn, Sage Publications, Los Angeles, Calif.

ZADEK, S., Raynard, P. (1995). Accounting works: a comparative review of contemporary approaches to social and ethical accounting. Accounting Forum, vol. 19, no. 2/3, pp. 164-175.

ZADEK, S. (2004). The Path to Corporate Responsibility. Harvard business review, vol. 82, no. 12, pp. 125-132.

ZHANG, J., Fraser, I., Hill, W.Y. (2003). A comparative study of social audit models and reports. In, J. Andriof, S. Waddock, B. Husted, S. Sutherland Rahman, eds. Unfolding Stakeholder Thinking: Relationships, Communication, Reporting and Performance, 2nd edn, Greenleaf Publishing, pp. 244266. 